\title{
Using a Bayesian Modelling Approach to Understand the Redistribution of Pottery to Romano-British Rural Sites
}

\begin{abstract}
The vast majority of inhabitants of Roman Britain lived in the countryside. However, the redistribution of pottery to Romano-British rural sites is poorly understood. To address this issue, a Bayesian approach (Integrated Nested Laplace Approximation, INLA) is used to model the count of pottery recovered from rural sites. Through model selection, the redistribution of pottery was identified to be driven by small towns and pottery production sites. Findings also suggest that the redistribution of pottery was not homogenous across site types, with Roman roads and local trackways playing an important role.
\end{abstract}

\section{Introduction}

With an estimated 80-90 per cent of inhabitants of Roman-Britain living in the countryside ${ }^{1}$, understanding how the rural population interacted within a 'Romanised' society is fundamental to knowledge of the province ${ }^{2,3}$. Traditionally the countryside has been understood through the interpretation of Roman villas ${ }^{4,5}$. However, villas are no longer seen as representative - making up only 1 per cent of known rural sites, and largely found in the southern and eastern counties of England ${ }^{6}$. Recent initiatives have aimed to address this bias through the large-scale collection and review of a wider range of rural sites, opening up new ways to understand local-, regional-, and provincial-level patterns in the distribution of Roman material culture in rural sites ${ }^{3,7}$.

Although the distribution of pottery has played a major role in the study of trade in Romano-Britain $^{8-16}$, rural sites have stimulated disproportionately few studies ${ }^{12-15,17}$ despite likely representing the vast majority of demand ${ }^{12,15}$. Nonetheless, due to its ubiquity and durability ${ }^{18}$, general findings on the distribution of pottery in rural sites can be outlined: samian pottery (terra sigillata), a type of mass-produced table ware widely redistributed across the Roman Empire, are virtually present at all rural sites ${ }^{14,15,17}$; mortaria, a bowl used for preparing food and introduced to Roman Britain post-conquest, are found in large quantities at rural sites ${ }^{19-21}$; and finally, amphorae, containers for high-value agricultural goods associated with the Roman army, are not found in high frequency at rural sites ${ }^{15}$. 
Whilst this widespread distribution and high frequency of pottery has been used to develop our understanding of the role of 'small towns' and other sites on the road network for the redistribution of locally produced pottery ${ }^{8-10,13,22-24}$, there remains the need for a province-level assessment of how different pottery classes - whether locally produced or imported - were redistributed to rural sites, as well as establishing whether there are systematic differences in the redistribution of pottery based on site type $2,12,22,25$.

Using a province-wide dataset on rural sites and pottery (samian, mortaria, and amphorae) arising from 25 years of developer-funded excavations ${ }^{26}$ and the Integrated Nested Laplace Approximation (INLA) Bayesian modelling framework ${ }^{27}$, this study has two objectives: (1) estimate the association between covariates and the redistribution of pottery to rural sites through model selection, and (2) estimate the differences in the redistribution of different pottery classes based on site type.

\section{Methods}

\section{Data sources}

The study area was the whole of Roman Britain, with the location and information on rural sites derived from The New Visions of the Countryside of Roman Britain project - a largescale synthesis of grey-literature accumulated from commercial archaeological work conducted in advance of development since $1990^{26}$. The dataset totals 3,652 rural sites (3,338 sites with no villa building and 314 with villa building), with 146,659, 42,894, and 54,716 samian, mortaria, and amphorae sherds, respectively. Missing count of sherds with no presence of pottery reported were hardcoded to zero. Information on the major site type, presence of trackways, and presence of a villa building were also recorded for each rural site. To account for geographical variation in the distribution of villas, nucleated settlements and different classes of farmstead, The New Visions of the Countryside of Roman Britain project divided Roman Britain into eight distinct regions: the North, the North-East, the Central West, Upland Wales and the Marches, the Central Belt, the East, the South, and the South-West ${ }^{3}$. Although not to be regarded as homogenous entities, with each region showing considerable intra-regional diversity, the eight regions allow for inter-

regional comparison ${ }^{3}$. Data on 95 small towns were collated from Millett ${ }^{1}$; 264 pottery production sites were collated from The New Visions of the Countryside of Roman Britain 
project $^{26}$; the digitised Roman road network based on Roman roads identified by Margary was downloaded from Bishop ${ }^{28,29}$; whilst the digitised Roman era rivers dataset based on the Barrington Atlas of the Greek and Roman World was downloaded from the Ancient World Mapping Center ${ }^{30,31}$.

\section{Covariates}

This analysis includes eight covariates (4 linear- and 4 non-linear): (1) region; (2) major site type (rural settlement, communications, industry, military, nucleated settlement, religious ritual and funerary, and rural landscape); (3) presence of villas (yes/no); (4) presence of trackways (yes/no); (5) log-transformed Euclidean distance from rural site to nearest 'small town'; (6) log-transformed Euclidean distance from rural site to nearest pottery production site; (7) log-transformed Euclidean distance from rural site to Roman road network; and (8) log-transformed Euclidean distance from rural site to river. The use of non-linearity for the distance to- covariates reflects the assumption that the relationship to the count of pottery is non-linear. To account for rural sites, small towns, and pottery production sites having the same coordinates, the $\mathrm{x}$ - and $\mathrm{y}$-coordinates of the small towns and pottery production sites were independently jittered by a random value sampled from a Uniform $(-50,50)$. This reflects the locational accuracy of the two datasets which are accurate to within a $100 \mathrm{~m}$ square.

\section{Model implementation}

The Bayesian models were fitted using the Integrated Nested Laplace Approximation (INLA) $\mathrm{R}_{\text {package }}{ }^{27}$. Four Zero-inflated Poisson (ZIP) regression models were fitted to the count of samian, mortaria, and amphorae sherds recovered from rural sites (Table 1). A ZIP regression model was used due to an excess in zero counts ${ }^{32}$, with $46,68,75 \%$ of samian, mortaria, and amphorae, respectively, containing zeroes. Unstructured variability in the count of pottery sherds in rural sites was modelled using a unit-level independent random effect ${ }^{33}$. To allow for possible non-linear relationships, the log transformed distance to the nearest small town, pottery production site, road, and river were modelled using a second order random walk $(r w 2)^{33}$. Default priors of $\operatorname{Normal}(0,1000)$ and $\log \operatorname{Gamma}\left(1,10^{-5}\right)$ were used for the fixed and random effects, respectively ${ }^{33}$. 
Table 1. Candidate models with covariates

\begin{tabular}{ll}
\hline Model & Covariates \\
\hline A & Region \\
B & Region + Site Type + Trackway + Villa Building \\
C (Market redistribution) & Region + Site Type + Trackway + VillaBuilding $+f(\log ($ Town $))$ \\
& $+f(\log ($ Pottery $))$ \\
D (Military redistribution) & Region + Site Type + Trackway + VillaBuilding $+f(\log ($ Road $))$ \\
& $+f(\log ($ River $))$ \\
\hline
\end{tabular}

\section{Model Selection}

To select the model that best predicts the count of samian, mortaria, and amphorae sherds, the four models were compared with the use of the Watanabe-Akaike information criterion $(\text { WAIC })^{34}$. For each of the candidate models, the model which returns the lowest WAIC score is best supported by the data.

\section{Results}

Model C (market redistribution model) results in a lower WAIC for predicting the count of samian, mortaria, and amphorae pottery recovered from rural sites, with the inclusion of distance to nearest small town and pottery production site resulting in more accurate estimated values (Table 2). 
Table 2. Computed WAICs for the four models for each pottery class

\begin{tabular}{|c|c|c|}
\hline Model name & Covariates & WAIC \\
\hline \multicolumn{3}{|l|}{ Samian } \\
\hline$A$ & Region & 15,551 \\
\hline B & Region, Site type, Trackways, Villa building & 15,105 \\
\hline C & $\begin{array}{l}\text { Region, Site type, Trackways, Villa building, Distance to small } \\
\text { town, Distance to pottery production site }\end{array}$ & 15,082 \\
\hline $\mathrm{D}$ & $\begin{array}{l}\text { Region, Site type, Trackways, Villa building, Distance to road, } \\
\text { Distance to river }\end{array}$ & 15,101 \\
\hline \multicolumn{3}{|l|}{ Mortaria } \\
\hline$A$ & Region & 9,941 \\
\hline B & Region, Site type, Trackways, Villa building & 9,746 \\
\hline C & $\begin{array}{l}\text { Region, Site type, Trackways, Villa building, Distance to small } \\
\text { town, Distance to pottery production site }\end{array}$ & 9,678 \\
\hline $\mathrm{D}$ & $\begin{array}{l}\text { Region, Site type, Trackways, Villa building, Distance to road, } \\
\text { Distance to river }\end{array}$ & 9,727 \\
\hline \multicolumn{3}{|l|}{ Amphorae } \\
\hline$A$ & Region & 10,972 \\
\hline B & Region, Site type, Trackways, Villa building & 10,336 \\
\hline C & $\begin{array}{l}\text { Region, Site type, Trackways, Villa building, Distance to small } \\
\text { town, Distance to pottery production site }\end{array}$ & 10,190 \\
\hline $\mathrm{D}$ & $\begin{array}{l}\text { Region, Site type, Trackways, Villa building, Distance to road, } \\
\text { Distance to river }\end{array}$ & 10,349 \\
\hline
\end{tabular}

Figure 1 shows that distance to nearest small town has a significantly positive and negative estimated effect on the count of samian and amphorae sherds at short and long distances; with the estimated effect most significant for amphorae. This is in contrast to the count of mortaria which shows no significance at all, irrespective of distance from nearest small town. 
Similarly, short distances to the nearest pottery production site show a significantly positive estimated effect on the count of samian, mortaria, and amphorae sherds, with mortaria being most significant. A significantly negative association with count of samian, mortaria, and amphorae is also present at longer distances from the nearest pottery production site with mortaria again being the most significant.

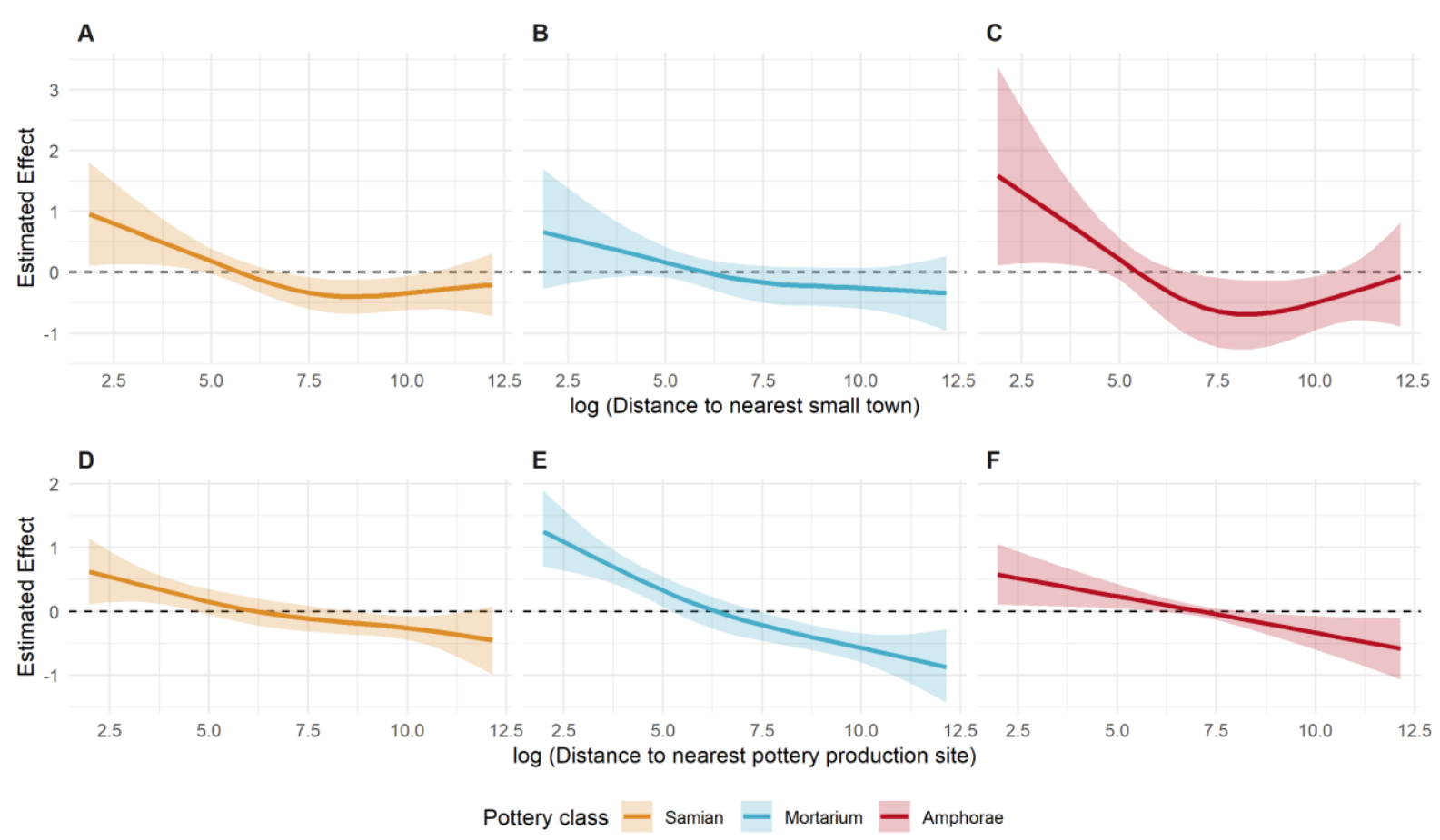

Figure 1. Estimated effect of distance to nearest small town (top row) and distance to nearest pottery production site (bottom row) on the count of samian, mortaria, and amphorae sherds presented as smoothed functions with $95 \%$ credible interval using Model C (market redistribution model)

The mean, 2.5th percentile, and 97.5th percentile for each parameter of the fixed effects included in Model C are shown in Figure 2. Results show that the count of samian sherds at rural sites in all regions were significantly lower than the count at rural sites in the south region; the count of amphora sherds was only significantly lower in the central belt and east regions. Furthermore, the count of sherds for all three pottery classes in military and nucleated settlements was significantly higher than the rural settlements baseline. In contrast, only the count of samian and mortaria sherds in religious, ritual, and funerary sites and rural landscape was significantly higher than rural settlements; with the count of amphora showing no statistical difference. Finally, both the presence of trackways and a 
villa building showed a significantly positive estimated effect on the count of samian, mortaria, and amphorae pottery sherds in rural sites.

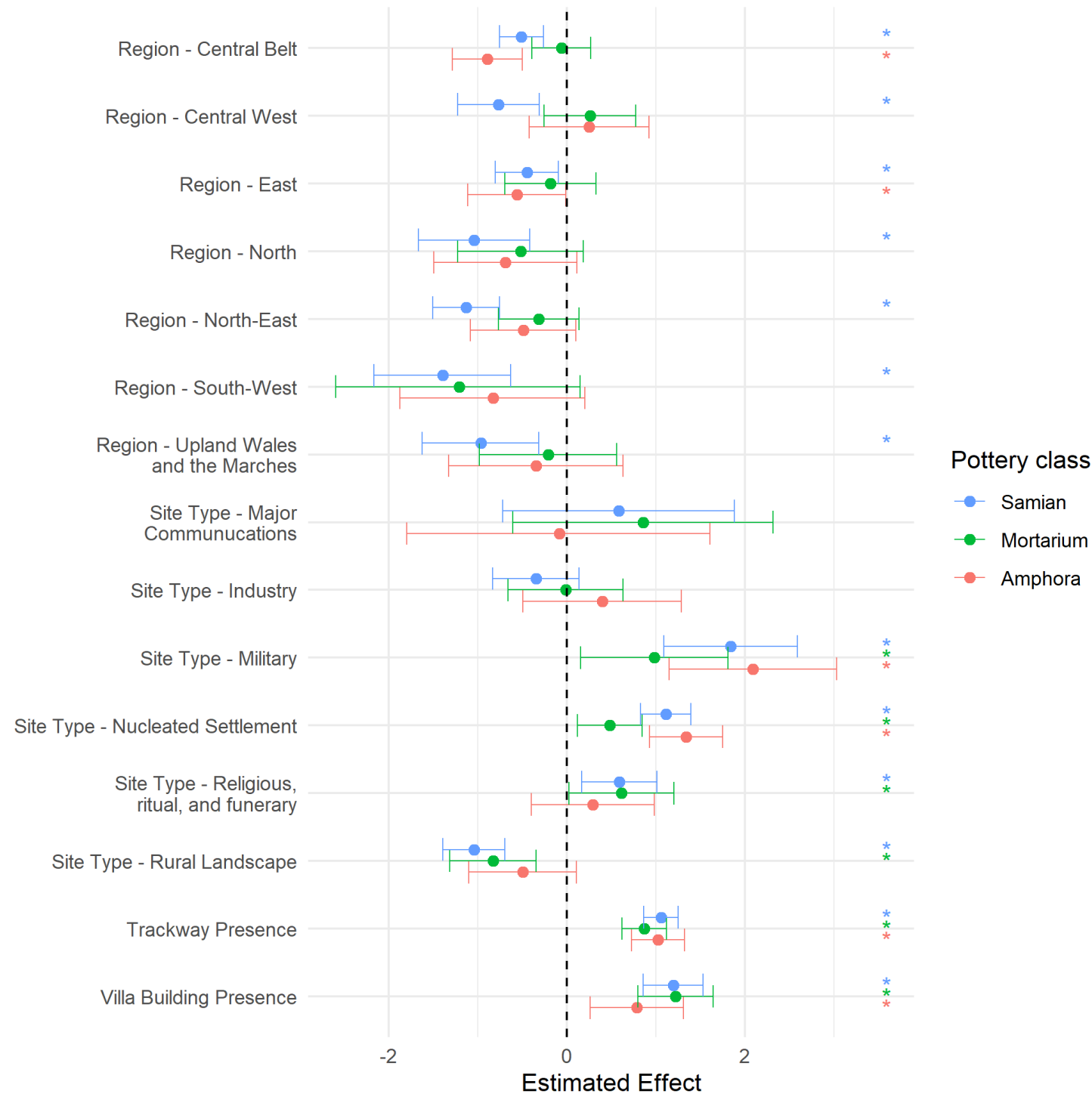

Figure 2. Marginal posterior point estimates of fixed effect covariates with $95 \%$ credible interval using Model C for the count of samian, mortaria, and amphorae sherds

\section{Discussion}

This study used a Bayesian approach to model the count of samian, mortaria, and amphorae sherds in rural sites in Roman Britain. Results from the model selection has shown that market redistribution of all three pottery classes from small towns to rural sites is applicable at a province-level; irrespective of whether the pottery was produced locally or imported 
from across the Roman Empire. Furthermore, the findings indicate that the redistribution of pottery to rural sites was not uniform, with the count of pottery sherds varying by site type.

The non-linear estimated effects show that whilst market redistribution best explain the count of pottery sherds present in rural sites, the role of small towns and pottery production sites differs depending on pottery class. The strong positive effect of short distances to nearest small town coupled with the weak positive effect of pottery production site on the count of samian and amphorae suggests that these two pottery classes were redistributed to rural sites via small towns. The importance of merchants and traders in the redistribution of samian and amphorae has previously been noted ${ }^{13,25}$; with the low demand for samian making towns acting as redistributive centres essential ${ }^{35}$. In contrast, the role of small towns for the redistribution of amphorae is less certain, with market centres, potters, and direct supply by the state all suggested as explanations ${ }^{25,35}$. In light of the results, however, this research suggests that the redistribution from small towns is applicable to explaining both the count of samian and amphorae in rural sites.

In contrast to samian and amphorae, the strong positive association of short distances to nearest pottery production site on the count of mortaria suggests that the mortaria was redistributed via pottery production sites. Whilst the direct redistribution of pottery from pottery production sites has previously been suggested ${ }^{25}$, this research is the first to show this quantitatively via regression analysis. The success of this redistribution is emphasised by the lack of positive or negative significance in the count of mortaria for all regions compared to the south; reflecting the previously noted widespread distribution of mortaria ${ }^{19,20,36}$. These results indicate that potters - rather than just making pottery and relying on small towns for redistribution - were active participants in the redistribution of pottery to the wider countryside.

The fixed effect relationships observed by the market redistribution model also show that there are significant differences in the count of pottery sherds based on site type. The significantly higher count of samian, mortaria, and amphorae at military sites and nucleated settlements - with both often developing along, or in relation to, major Roman roads ${ }^{3}-$ reflects the role Roman roads played in integrating rural sites to local market centres ${ }^{8,9}$. The importance of connectivity is further highlighted at a local rural site level - with the 
presence of trackways having a significantly positive estimated effect on the count of samian, mortaria, and amphorae sherds. Whilst the link between trackways, increased mobility, and the greater range of material culture in rural sites has been noted previously ${ }^{7,37}$, these results reaffirm the importance of both Roman roads and local trackways for understanding the interaction between rural sites and the wider province, and how this is reflected in the material culture.

The significantly positive effect of the presence of a villa on the count of samian, mortaria, and amphorae reflects what villas represent - a permanent building constructed at significant expense ${ }^{6} ;$ with the greater quantity of pottery likely reflecting a greater demand, driven by an aspiration towards roman cultural values. Although these results disagree with previous studies that found the proportion of samian at villas to be in line with other rural sites $^{13,35}$, it is suggested that this reflects how the comparisons are done - with this research comparing count of pottery sherds rather than proportions. Nonetheless, these findings have shown that at a province-level, the presence of a villa is significantly associated with an increase in the count of pottery sherds. Similarly, the significantly higher count of samian and mortaria in religious, ritual, and funerary sites is suggested to reflect their social importance as a votive and funerary ware ${ }^{12,38,39}$. Although previous studies have reported the low frequency of samian associated with temples and religious environments ${ }^{12,17}$ - with numbers similar to that of other rural sites - these results have again shown that although local patterns may be present, it does not guarantee the same at a province-level.

Lastly, the significantly negative effect of all other regions relative to the south on the count of samian is suggested to reflect the role of London as a major centre for importation and redistribution. The role of London in the development and redistribution of pottery has been highlighted previously, with the port handling trade from the rest of the Empire, whilst main roads radiating out were exploited by potters ${ }^{18,40-42}$.

Overall this research has shown that the redistribution of samian, mortaria, and amphorae pottery was driven by local markets - that is, small towns for samian and amphorae; and pottery production sites for mortaria. Furthermore, the redistribution of pottery depended on site type with notable conclusions: (1) the importance of not only Roman roads but also local trackways on the redistribution of pottery to rural sites; (2) the 
need for understanding redistribution of material culture at both the local and provincelevel; and (3) the importance of London for the importation and redistribution of samian pottery to the rest of the province. 


\section{References}

1. Millett, M. The romanization of Britain: an essay in archaeological interpretation. (Cambridge University Press, 1990).

2. Willis, S. The Study Group for Roman Pottery Research Framework Document for the study of Roman pottery in Britain, 2004. Journal of Roman Pottery Studies 11, 1-20 (2004).

3. New visions of the countryside of Roman Britain. (Society for the Promotion of Roman Studies, 2016).

4. Studies in the Romano-British villa. (Leicester University Press ; distributed in North America by Humanities Press, 1978).

5. Branigan, K. \& Miles, D. The Economies of Romano-British Villas. (J.R Collis Publications, 1988).

6. Millett, M. 'By Small Things Revealed'. vol. 1 (Oxford University Press, 2014).

7. Taylor, J. An atlas of Roman rural settlement in England. Council for British Archaeology Research Reports 151 (Archaeology Data Service, 2013). doi:10.5284/1081719.

8. Allen, J. R. L. \& Fulford, M. G. The Distribution of South-East Dorset Black Burnished Category I Pottery in South-West Britain. Britannia 27, 223 (1996).

9. Hodder, I. Some Marketing Models for Romano-British Coarse Pottery. Britannia 5, 340 (1974).

10. Hodder, I. Regression analysis of some trade and marketing patterns. World Archaeology 6, 172-189 (1974).

11. Willis, S. The Romanization of Pottery Assemblages in the East and North-East of England during the First Century A. D.: A Comparative Analysis. Britannia 27, 179 (1996).

12. Willis, S. Samian Pottery in Britain: Exploring its Distribution and Archaeological Potential. Archaeological Journal 155, 82-133 (1998).

13. Willis, S. Samian Ware and Society in Roman Britain and Beyond. Britannia 42, 167$242(2011)$.

14. Booth, P. The occurrence and use of samian ware in rural settlements in the Upper Thames Valley. in Dating and Interpreting the Past in the Western Roman Empire: Essays in Honour of Brenda Dickinson (ed. Bird, D.) (Oxbow Books, 2012). 
15. Evans, J. Balancing the Scales: Romano-British Pottery in Early Late Antiquity. Late Antiq Archaeol 10, 425-450 (2013).

16. Fulford, M. \& Hodder, I. A Regression Analysis of Some Late Romano-British Pottery: A Case Study. Oxoniensia 39, 26-33 (1974).

17. Willis, S. Samian Pottery, a Resource for the Study of Roman Britain and Beyond: the results of the English Heritage funded Samian Project. An e-monograph. IA (2005) doi:10.11141/ia.17.1.

18. Fulford, M. Economic Structures. in A Companion to Roman Britain (ed. Todd, M.) 309-326 (Blackwell Publishing Ltd, 2004). doi:10.1002/9780470998861.ch17.

19. Cool, H. E. M. Eating and Drinking in Roman Britain. (Cambridge University Press, 2006). doi:10.1017/СВ09780511489570.

20. Cramp, L. J. E., Evershed, R. P. \& Eckardt, H. What was a mortarium used for? Organic residues and cultural change in Iron Age and Roman Britain. Antiquity 85, 1339-1352 (2011).

21. Rush, P. Symbols, Pottery and Trade. Theoretical Roman Archaeology Journal 0, 55 (1997).

22. Fulford, M. et al. Chapter 7: Movement of Resources. in New visions of the countryside of Roman Britain. Volume 2: The Rural Economy of Roman Britain (eds. Allen, M., Brindle, T., Fulford, M., Lodwick, L. \& Rohnbogner, A.) 281-357 (Society for the Promotion of Roman Studies, 2017).

23. Booth, P. Inter-site comparisons between pottery assemblages in Roman Warwickshire: ceramic indicators of site status. Journal of Roman Pottery Studies 1-10 (1991).

24. Griffiths, K. Marketing of Roman pottery in second century Northamptonshire and the Milton Keynes area. Journal of Roman Pottery Studies 2, 66-76 (1989).

25. Peacock, D. P. S. Pottery in the Roman world: an ethnoarchaeological approach. (Longman, 1982).

26. Allen, M. et al. The Rural Settlement of Roman Britain: an online resource. (2015) doi:10.5284/1030449.

27. Rue, H., Martino, S. \& Chopin, N. Approximate Bayesian inference for latent Gaussian models by using integrated nested Laplace approximations. Journal of the Royal Statistical Society: Series B (Statistical Methodology) 71, 319-392 (2009). 
28. Bishop, M. C. The secret history of the Roman roads of Britain. (Pen \& Sword Military, 2014).

29. Margary, I. D. Roman roads in Britain. (J. Baker, 1973).

30. Talbert, R. J. A. Barrington atlas of the Greek and Roman world. (2000).

31. Ancient World Mapping Center. Roman Era Rivers. https://awmc.unc.edu/awmc/map_data/shapefiles/physical_data/ba_rivers/ (2021).

32. Lambert, D. Zero-Inflated Poisson Regression, with an Application to Defects in Manufacturing. Technometrics 34, 1 (1992).

33. Gómez-Rubio, V. Bayesian inference with Inla. (Taylor and Francis, CRC Press, 2020).

34. Watanabe, S. Asymptotic Equivalence of Bayes Cross Validation and Widely Applicable Information Criterion in Singular Learning Theory. Journal of Machine Learning Research 11, 3571-3594 (2010).

35. Evans, J. Pottery function and finewares in the Roman North. Journal of Roman Pottery Studies 95-118 (1993).

36. Hartley, K. The marketing and distribution of mortaria. in Current research into Romano-British pottery 39-51 (Council for British Archaeology, 1973).

37. Booth, P. Romano-British Trackways in the Upper Thames Valley. Oxoniensia 76, 114 (2011).

38. Biddulph, E. Costing the (figured) earth: using samian to estimate funerary expenditure. in Dating and interpreting the past in the western Roman Empire: essays in honour of Brenda Dickinson (ed. Bird, D.) 295-304 (Oxbow Books, 2012).

39. Biddulph, E. On Cultural Selection: Examining the Process of Cultural Evolution through Funerary Evidence. Theoretical Roman Archaeology Journal 0, 76 (2012).

40. Marsh, G. D. London's samian supply and its relationship to the development of the Gallic samian industry. in Roman Pottery Research in Britain and NorthWest Europe. Papers Presented to Graham Webster 173-238 (British Archaeological Reports, 1981).

41. Dannell, G. Early decorated samian from London reassessed. in The Archaeology of Roman Towns (ed. Wilson, P.) 53-58 (Oxbow Books, 2003).

42. Milne, G. The port of Roman London. (B.T. Batsford, 1985). 